\title{
Overview of Multiple Applications of Basil Species and Cultivars and the Effects of Production Environmental Parameters on Yields and Secondary Metabolites in Hydroponic Systems
}

\author{
Teodor Rusu ${ }^{1, *} \mathbb{C}$, Reed John Cowden ${ }^{2}$, Paula Ioana Moraru ${ }^{1}$, Mihai Avram Maxim ${ }^{1}$ and Bhim Bahadur Ghaley ${ }^{2}$ \\ 1 Department of Technical and Soil Sciences, Faculty of Agriculture, University of Agricultural Sciences and \\ Veterinary Medicine Cluj-Napoca, 400372 Cluj-Napoca, Romania; paulaioana.moraru@usamvcluj.ro (P.I.M.); \\ mihai.maxim90@gmail.com (M.A.M.) \\ 2 Department of Plant and Environmental Sciences, Faculty of Science, University of Copenhagen, \\ 1165 København, Denmark; cowden@plen.ku.dk (R.J.C.); bbg@plen.ku.dk (B.B.G.) \\ * Correspondence: trusu@usamvcluj.ro; Tel.: +40-724-719-774
}

\section{check for} updates

Citation: Rusu, T.; Cowden, R.J.; Moraru, P.I.; Maxim, M.A.; Ghaley, B.B. Overview of Multiple Applications of Basil Species and

Cultivars and the Effects of Production Environmental Parameters on Yields and Secondary Metabolites in Hydroponic Systems. Sustainability 2021, 13, 11332. https://doi.org/10.3390/su132011332

Academic Editor: Stefania De Pascale

Received: 17 July 2021

Accepted: 11 October 2021

Published: 14 October 202

Publisher's Note: MDPI stays neutral with regard to jurisdictional claims in published maps and institutional affiliations.

Copyright: (c) 2021 by the authors. Licensee MDPI, Basel, Switzerland. This article is an open access article distributed under the terms and conditions of the Creative Commons Attribution (CC BY) license (https:/ / creativecommons.org/licenses/by/ $4.0 /)$.

\begin{abstract}
Basil (Ocimum basilicum L.), including other species and cultivars, is an excellent source of nutritional compounds, the accumulation of which can be stimulated by exogenous factors (environmental and nutritional conditions). Although best practices are relatively established for mature basil plants, microgreens production requires further research to optimize quality and quantity. The study objectives are (i) to provide an overview of the many uses of basil, (ii) collate and present common hydroponic systems available in the market, (iii) review effects of key production environment parameters on basil yields in hydroponic systems, and (iv) summarize the effects of the growth environments on yield quantity and quality of basil microgreens. The paper analyzes in detail key production parameters of basil microgreens in hydroponic systems, such as temperature, humidity, $\mathrm{pH}$, electrical conductivity, dissolved oxygen, carbon dioxide, nutrient solutions, and the influence of light (quantity, quality, and photoperiods). The collated literature review has shown that basil, grown hydroponically, can tolerate high variations of environmental parameters: $\mathrm{pH}$ 5.1-8.5, temperature $15-24{ }^{\circ} \mathrm{C}$, relative humidity $60-70 \%$, electrical conductivity up to $1.2 \mathrm{mS} \mathrm{cm}^{-1}$, depending on the developmental stage, dissolved oxygen at $4 \mathrm{mg} \mathrm{L}^{-1}$ (optimally $6.5 \mathrm{mg} \mathrm{L}^{-1}$ ), and light intensity between 200 and $400 \mu \mathrm{mol} \mathrm{m}^{-2} \mathrm{~s}^{-1}$. The study has synthesized an overview of different production parameters to provide guidance on the optimization of environmental conditions to ensure the quantity and quality production of basil microgreens. Improving the quality of basil microgreens can ideally spur continued gastronomic interest in microgreens in general, which will encourage more entrepreneurs to grow basil and other microgreens. Hence, the study findings are a great resource to learn about the effects of different environments on basil microgreen production. This information can inform research for successful production of different species and cultivars of basil microgreens, and establishing testing protocols to improve the quantity and quality of the harvest.
\end{abstract}

Keywords: basil; microgreens; hydroponic system; production environment parameters

\section{Introduction}

By 2050 it is estimated that the human population of the Earth will be approximately 10 billion people [1]. Meeting the caloric and nutritional needs of this growing population is a large challenge for humanity. The growing population based on urban agglomeration, in combination with limited natural resources and global warming, increases the severity of this challenge by posing a threat to food safety globally [2]. Conventional agriculture is ill-suited to meet this challenge, as it has negative impacts on the environment, inefficient use of a large quantity of water, high concentrations of nutrients and pesticides in water runoff, high greenhouse gas (GHG) emissions, and increases soil degradation and erosion. Therefore, in order to improve input use efficiencies and mitigate greenhouse 
gas emissions, hydroponic production systems can represent an alternative to the conventional methods of food production [1]. This literature review focused on the hydroponic production of microgreens with a growing period of 7-21 days that uses substrates of organic or inorganic origin (textile, coconut coir, perlite, etc.) instead of soil substrate. This is of contemporary value, as hydroponic standards for mature plants are relatively well established, while for microgreens, optimal conditions for quality and quantity production are still in development. In general, hydroponics production systems can reduce or avoid the use of insecticides, herbicides, or pesticides, which leads to a reduction in GHGs, while water can be reused, with a reduction in water consumption by up to $90 \%$ [3] compared to soil-based production in open fields. Furthermore, hydroponic systems have the advantage of controlling environmental parameters to obtain higher yields and uniform outputs while also improving resource use efficiency [4-6].

Microgreens, of which basil is one of the most popularly cultivated choices, are mainly produced hydroponically or semi-hydroponically with very short growing cycles (usually 10-20 days after germination) and are considered the functional food of the 21st century [7]. This is because they are young plants consumed at a seedling stage with a high nutrient density, have a short production cycle, and need little space to grow. Microgreens are seedlings of vegetables and herbs consumed with tender cotyledons, and the first pairs of leaves are more or less developed. At harvest, plant height varies from 2.5 to $8 \mathrm{~cm}$ depending on the species [8]. Microgreens are functional crops rich in valuable nutritional elements that are beneficial for human health when used as food supplements. Apart from the larger concentration of nutrients per gram in microgreens compared to mature plants, the taste and aroma are much more intense than mature plants, which makes them ideal for gastronomic purposes. Microgreens are also an alternative to sprouts (germinated seeds) due to their higher content of vitamins, carotenoids, and phenols, as well as their reduced content of nitrates [9]. This is in part due to the controlled environment, which can optimize beneficial compound production.

Hydroponically cultivated microgreens are of increasing importance because of their high nutraceutical properties, but data regarding yield, quality, and nutritional quantity, and factors that influence these properties are limited and still in their early stages [10]. Furthermore, operational practices, including nutrient solution compositions, mineral requirements, and light regimes, have not been standardized yet. Therefore, potential low yields are usually indicated as a limiting factor for microgreen production [11-13]. Furthermore, no standard guidelines for quality exist [14], although there are consumer standards such as color and taste that are threshold values of quality and consumer acceptance. However, research is being increasingly focused in this area to determine the protocols necessary to maximize the value of microgreen production. This literature review is focused on these recent papers, as they pertain to basil species or cultivars, with the purpose of collating important syntheses of novel research to harmonize the many disparate sources of information.

Hydroponic production of microgreens offers the potential to produce fresh crops with a short production cycle that have a high concentration of nutrients, vitamins, and beneficial secondary metabolites [15]. Hydroponics practices are increasingly popular due to the perceptions concerning conventional agriculture's impact on the food supply and human health [16]. However, there are a number of challenges faced by the microgreens producers, hindering the development of this sector. Firstly, there are a number of hydroponics systems available in the market, and it can be difficult for a producer to decide on a particular hydroponic system. Secondly, production parameters viz. light intensity, light quality (spectrum combinations) and photoperiod, $\mathrm{pH}$, electrical conductivity, air, and water temperature, nutrient solution, $\mathrm{CO}_{2}$ content, and air circulation have huge effects on the crop yield in terms of quantity and quality, and best practices for a particular production objective (quality and quantity) do not exist. Thirdly, there is wide speciesspecific and cultivar-specific variation in crop yields and nutritional contents under similar production environments for microgreens. Hence, this study provides insights into these 
key challenges in hydroponic production, with a focus on basil species and cultivars, by synthesizing a variety of sources of relevant information. The information presented here contributes to a more nuanced comprehension of the challenges of basil microgreen production in a controlled hydroponic system, which leads to the further development of research and industry to fine-tune optimal production of high-quality, nutrient-dense basil microgreens. Therefore, the study objectives were to:

1. Provide an overview of the multiple uses of basil;

2. Collate and present common hydroponic systems available in the market;

3. Review effects of key production environmental parameters on basil yields in quantity and quality in hydroponic systems;

4. Summarize the effects of the growth environments on basil microgreen yield quantity and quality.

\section{Materials and Methods}

This literature review is a systematic organization of the information on the multiple applications of basil and the contemporary research trends on environmental parameters necessary for their successful growth and quality production. This was done to present a synthesis of key information on the quality and quantity production of microgreens. The literature review was conducted between December 2020 and August 2021, using the databases: Web of Sciences, Scopus, Science Direct, and Google Scholar. This was done to synthesize data from a diversity of experiments on the successful production of hydroponic basil microgreens by collating the literature on environmental parameterization and production processes. The review of the literature and data collection used a number of keywords relevant for the production of basil microgreens in hydroponic systems, such as: temperature, humidity, $\mathrm{pH}$, electrical conductivity, oxygen dissolved in water, carbon dioxide, nutrient solutions, and the influence of light (quantity, quality, and photoperiods). The data collected were structured to provide a more nuanced comprehension of the challenges of basil microgreen production in controlled hydroponic systems, which can help further the research and development needs on basil production, as well as elaborate on adequate cultivation protocols for controlled environment parameterization.

\section{Results}

\subsection{Multiple Applications of Basil}

Basil (Ocimum basilicum L.), Labiatae Fam., including other cultivars and species, has many uses such as seasoning, medicine, ornamental, and industrial applications such as cosmetic production (Table 1). For instance, basil is used both in traditional and scientific medicine due to the presence of health-promoting compounds and essential oils. For instance, basil essential oils have an important role in reducing inflammation, muscle spasms, have antibacterial and antifungal activity, and have a beneficial influence on the respiratory and digestive system [1,15]. The World Health Organization (WHO) has estimated that medicines based on plants, especially extracts of plants, are used by almost $80 \%$ of the world population for their first course of treatment [17]. In this regard, Basil is often used in traditional medicine, especially against intestinal worms, flu, or kidney disease, for the carminative effect (that relieves abdominal pain and promotes the evacuation of intestinal gas), and even for the treatment of insect or snake bites [18]. 
Table 1. Multiple uses of basil products.

\begin{tabular}{|c|c|c|}
\hline No. & References & Use and Advantages of Basil \\
\hline 1 & [19-21] & $\begin{array}{l}\text { Used in traditional medicinal tea for the treatment of bronchial asthma, pertussis, etc., and } \\
\text { pharmaceutical products are used for the treatment of inflammation of the airways, as a tonic } \\
\text { of the nervous system, or as an antispasmodic remedy }\end{array}$ \\
\hline 2 & [22] & Substances extracted have a fungicidal effect, and grain plants treated with it remained healthy \\
\hline 3 & {$[23,24]$} & Has antibacterial, antioxidant, and antitumor effects \\
\hline 4 & {$[25,26]$} & $\begin{array}{c}\text { Volatile oil can also be used as a repellent against Culex pipiens, a mosquito that spreads diseases such as meningitis, or } \\
\text { against fire blight (Erwinia amylovora) }\end{array}$ \\
\hline 5 & [27] & Fresh juice can be used in otitis (inflammation or infection of the ear) \\
\hline 6 & [28] & $\begin{array}{l}\text { Volatile oil has been shown to prevent the development of Fulvia fulva, Glomerella } \\
\text { cingulata, Alternaria alternate, and Fusarium solani var. coeruleum phytopathogens in lab conditions }\end{array}$ \\
\hline 7 & [29] & $\begin{array}{l}\text { Volatile oil and extracted estragole, linalool, methyl-eugenol, and trans-anethole compounds } \\
\text { have shown insecticidal effects on Ceratitis capitata, Bactrocera dorsalis, and Bactrocera } \\
\text { cucurbitae fruit flies }\end{array}$ \\
\hline 8 & [18] & $\begin{array}{l}\text { Often been used in traditional medicine, especially against intestinal worms, flu, or kidney } \\
\text { disease, for the carminative effect (that relieves abdominal pain and promotes the evacuation } \\
\text { of intestinal gas) and even for the treatment of insect or snake bites }\end{array}$ \\
\hline 9 & [30] & $\begin{array}{l}\text { Has shown positive impacts on diseases such as: depression, neurosis, dysfunctions of the } \\
\text { sweat, adrenal, mammary, and sexual glands, diseases of the respiratory system (asthma, } \\
\text { bronchitis, cold and flu, allergy), nausea, liver and gallbladder disease, kidney disease, } \\
\text { rheumatisme, parasitic disease, insect bites and different types of skin cancer }\end{array}$ \\
\hline 10 & [31] & Has been widely cultivated globally and used to reduce the serum lipid content \\
\hline 11 & [32] & $\begin{array}{c}\text { Extraction of ethyl alcohol has shown an antibacterial effect in the case of Escherichia coli, } \\
\text { Pseudomonas auruginosa, Proteus mirabilis, Klebsiella pneumoniae, Staphylococcus aureus, } \\
\text { and Enterococcus faecalis pathogens, in certain concentrations equaling the effectiveness of } \\
\text { synthetic antibacterial substances }\end{array}$ \\
\hline 12 & {$[33,34]$} & $\begin{array}{l}\text { Known to have stimulant-digestive, bactericidal, antifungal, spasmolytic, carminative, } \\
\text { galactogoge, expectorant, antipyretic, febrifuge, diuretic, sedative, and anti-inflammatory } \\
\text { properties. Cultivated for use in the perfume industry to prepare different cosmetic products } \\
\text { such as perfumes, soaps, shampoos, and toothpaste, for example }\end{array}$ \\
\hline 13 & [1] & $\begin{array}{l}\text { Volatile oils (methylchavicol, linalool) reduced the development of the Botrytis fabae } \\
\text { phytopathogen in grain (Vicia faba) in vitro conditions }\end{array}$ \\
\hline 14 & [35] & $\begin{array}{l}\text { Volatile oils have proven effective against Staphylococcus aureus and Pseudomonas } \\
\text { aeruginosa pathogens, acting even synergistically with certain antibacterial substances }\end{array}$ \\
\hline 15 & [36] & Can be used in the food industry as a preservative and antioxidant for different food products \\
\hline 16 & [17] & $\begin{array}{l}\text { The World Health Organization (WHO) has estimated that medicines based on plants, } \\
\text { especially extracts of plants, are used by almost } 80 \% \text { of the world population for their first treatment }\end{array}$ \\
\hline 17 & [15] & $\begin{array}{l}\text { Can be used for the treatment of a wide range of diseases and ailments: diarrhea, dysentery, } \\
\text { nausea, vomiting, gastric ulcer, biliary colics, bloating, flatulence, aerophagia, fermentation } \\
\text { colitis, abdominal cramps, anorexia, migraines, neuroses, depression, insomnia, headaches, } \\
\text { gonorrhea, acne, thrush, stomatitis, etc. }\end{array}$ \\
\hline 18 & [37] & $\begin{array}{l}\text { Essential oils have been used in a new type of packing system to extend the validity period of } \\
\text { food: microcapsules and packing systems that inhibit the bacterial activity and increase the } \mathrm{pH} \text { of packed food }\end{array}$ \\
\hline 19 & [38] & $\begin{array}{l}\text { Essential oils have shown effectiveness when used in cosmetic formulations and food } \\
\text { supplements as antioxidant agents }\end{array}$ \\
\hline
\end{tabular}

In general, the aboveground plant parts of basil are used to extract the volatile oil and compounds. Studies show that the aboveground plant parts of the basil (Basilici herba) contain around $0.04-0.7 \%$ (Aetheroleum basilici) [34], $0.2-0.5 \%$ [39], or $0.2-1 \%$ volatile oils [ 40 ]. The volatile oil content of basil plants can vary between $0.2 \%$ and $1 \%$, reaching up to $1.7 \%$ based on the origin of the biological material and the phenological stage of plants [41]. According to the composition of its volatile oil, basil can be grouped into four chemotypes [15]: (1) rich in methyl-chavicol, (2) rich in linalool, (3) rich in methyl-eugenol, and (4) rich in methyl-cinnamate [42]. In accordance with the geographical origin of the types of basil, there exists a European chemotype with linalool (35-50\%) and estragole $(15-25 \%)$ as main compounds; a reunion chemotype, with $80 \%$ estragole in its volatile oil; a tropical chemotype (cinnamon basil) with a high percentage of methyl-cinnamate; and a eugenol chemotype rich in eugenol [43]. Furthermore, Milică et al. [33] list the following active substances in basil: volatile oil (containing estragole, linalool, ocimene, cineole, camphor, and eugenol as main compounds), flavonoids (apigenin), glycosides (esculin, esculetin), saponins, triterpene saponosides, tannins, phenolic acids (cafeic, ferulic, 
cinamic, ursolic), vitamins and mineral salts [44]. Kutta [41] lists 140 compounds identified in the volatile oil of basil, of which over 30 are monoterpene, almost 30 are sesquiterpene, with 20 derivates of carboxylic acids, 11 aliphatic aldehydes, 6 aliphatic alcohols, and over 20 aromatic compounds.

Flavonoids and other phenolic compounds are secondary metabolites of plants, and they are known to have beneficial effects on the human body. Currently, more than 8000 phenolic compounds have been identified [45]. Their antioxidant, anticancer, antimicrobial, cardioprotective, and anti-inflammatory effects have been demonstrated in previous research [45]. Phenolics have an antioxidant effect that is more effective even than that of certain vitamins [46]. Different studies have concluded that basil contains significant amounts of phenolic substances with antioxidant effects, for example, chicoric acid [47], rosmarinic acid, and cafeic acid [48]. Their quantity varies according to the basil cultivars, with values between 3.47 and $17.58 \mathrm{mg} \mathrm{g}^{-1}$ dry matter expressed in gallic acid equivalents [49]. It has also been demonstrated that there is even a diurnal variation of secondary metabolites accumulated in the plant [50]. The harvesting time during the day can therefore be quite important in order to obtain the desired secondary metabolites. Besides the above-mentioned aspects, basil also contains carotene, vitamin $\mathrm{A}, \mathrm{B}_{6}$, and $\mathrm{C}$, calcium, potassium, phosphorus, magnesium, and iron [51,52]. All of these nutrient incidences add to basil's potential uses and value and necessitate the effective parameterization of the basil microgreen production environment via hydroponic systems to optimize their beneficial compound content. Furthermore, most of the above-mentioned studies used mature basil as their study units; therefore, the concentrations of these valuable compounds and their production during the microgreens phenological stages is an important avenue of future research. Previous research has already shown that microgreens have higher concentrations of nutrients; it is, therefore, likely that it also produces many other valuable secondary metabolites at a high concentration as well, thereby adding to basil's value [9].

Besides its uses in medicine, cultivating basil can be done for seasoning or food application purposes. For instance, the aerial parts of the plant have been used for the seasoning of different sauces, foods, pasta, sausage, and pickles. Basil can also be used in the food industry, where it can be added as a preservative and antioxidant to different food products [36]. This is because the Herba variety (Herba Basilici), which contains volatile oil in the range of $0.5-1.5 \%$ and is rich in estragole (up to $80 \%$ ) and in linalool [53], has antimicrobial and antifungal properties. For example, basil essential oil has been used to prepare a new type of packing system to extend the shelf life of food: microcapsules and packing systems that inhibit the bacterial activity and increase the $\mathrm{pH}$ of packed food [37].

Beyond medicine and gastronomic purposes, basil extracts can also be used to prepare liqueur [15]. Basil is also cultivated for use in the cosmetic industry to prepare different products such as perfumes, soaps, shampoos, and toothpaste, to name a few [33]. Tacchini et al. [38] also demonstrated the importance of using basil essential oil (EO) in cosmetic formulations and food supplements as antioxidant agents.

\subsection{Overview of Hydroponics Systems for Basil Microgreen Production}

Hydroponics, or "soilless" plant cultivation, involves growing plants in a nutrient solution consisting of water and nutrients or using an inert and porous substrate (mineral wool, clay, perlite, vermiculite, etc.) that helps retain the nutrient solution and facilitate oxygenation of the roots for plant growth. The common hydroponic systems currently available in the market are provided in Table 2. 
Table 2. Overview of hydroponic systems available on the market.

\begin{tabular}{|c|c|c|c|}
\hline No. & Systems & Characteristics & Website \\
\hline 1 & Wick System & $\begin{array}{l}\text { The plants are placed in a container on an absorbent growth } \\
\text { medium, and the connection to the tank with nutrient } \\
\text { solution is made with absorbant wicks, through which the } \\
\text { nutrient solution diffuses to the level of the plant roots. }\end{array}$ & $\begin{array}{l}\text { www.hydroponics.eu } \\
\text { (accessed on } 1 \text { July 2021) }\end{array}$ \\
\hline 2 & Drip System & $\begin{array}{l}\text { The plants are installed in a medium, and the nutrient } \\
\text { solution is transported from the solution tank through drip } \\
\text { tubes; the excess solution reaches the tank again and } \\
\text { recirculates through the system. }\end{array}$ & $\begin{array}{c}\text { www.trees.com } \\
\text { (accessed on } 1 \text { July 2021) }\end{array}$ \\
\hline 3 & $\begin{array}{l}\text { Ebb and Flow } \\
\text { System }\end{array}$ & $\begin{array}{l}\text { It works by flooding and then draining the growing } \\
\text { environment in which the roots of plants with nutrient } \\
\text { solution are located. A pump pushes the nutrient solution } \\
\text { out of the tank, and then the excess drains back slowly, } \\
\text { allowing the plants to receive nutrients regularly. }\end{array}$ & $\begin{array}{l}\text { www.nosoilsolutions.com } \\
\text { (accessed on } 1 \text { July 2021) }\end{array}$ \\
\hline 4 & $\begin{array}{l}\text { Deep Water } \\
\text { Culture (DWC) } \\
\text { System }\end{array}$ & $\begin{array}{l}\text { The plants have their roots immersed directly in the nutrient } \\
\text { solution and float above it. As support, one can use } \\
\text { expanded polystyrene plates with perforations in which the } \\
\text { plants are inserted. Oxygenation of the solution is necessary. }\end{array}$ & $\begin{array}{l}\text { www.epicgardening.com } \\
\text { (accessed on } 1 \text { July 2021) }\end{array}$ \\
\hline 5 & $\begin{array}{l}\text { Nutrient Film } \\
\text { Technology } \\
\text { (NFT) }\end{array}$ & $\begin{array}{l}\text { This system ensures a constant flow of nutrient solution } \\
\text { directly to the plant roots. The plants are grown in } \\
\text { perforated polyethylene tubes and PVC pipes. }\end{array}$ & $\begin{array}{l}\text { www.thespruce.com } \\
\text { (accessed on } 1 \text { July 2021) }\end{array}$ \\
\hline 6 & $\begin{array}{l}\text { Aeroponic } \\
\text { System }\end{array}$ & $\begin{array}{l}\text { This system suspends the plants on top of a water pump that } \\
\text { directly sprays the roots with nutrient solution every few } \\
\text { minutes. The advantages of this system are the use of a much } \\
\text { smaller amount of water, the roots receive oxygen in large } \\
\text { quantities, and the plants grow faster. However, the roots of } \\
\text { the plants being suspended in the air are more prone to } \\
\text { drying faster than in any other hydroponic system. }\end{array}$ & $\begin{array}{l}\text { https: / / aeroponicsdiy.com } \\
\text { (accessed on } 1 \text { July 2021) }\end{array}$ \\
\hline 7 & $\begin{array}{l}\text { Aquaponic } \\
\text { Systems }\end{array}$ & $\begin{array}{l}\text { Aquaponics integrates aquaculture and hydroponics into a } \\
\text { single culture system. The water used in these crops } \\
\text { normally comes from the fish farming system. The fish } \\
\text { secrete nitrogen compounds that are captured and used by } \\
\text { plants in their growth, prolonging water use and reducing } \\
\text { the adjustment of the nutrient solution for plants. }\end{array}$ & $\begin{array}{l}\text { www.futurefarming.group } \\
\text { (accessed on 1 July 2021) }\end{array}$ \\
\hline
\end{tabular}

\subsection{Production Environment in Hydroponics Systems}

In a hydroponic system, basil successfully tolerates some variation of environmental parameters. The main environmental conditions that influence the development of microgreens in the hydroponic system are: light (photoperiodicity, light intensity, color spectrum), $\mathrm{pH}$, electrical conductivity (EC), dissolved oxygen, air and water temperature, $\mathrm{CO}_{2}$ concentration, and relative humidity. Table 3 provides a synthesis of production environment factors, based on the literature analyzed, for the achievement of successful growth and development of basil microgreens. Following the analysis of the reviewed literature, we have synthesized the following average values for basil's range of tolerance: $\mathrm{pH}$ in a range of $5.1-8.5$, temperature $15-24{ }^{\circ} \mathrm{C}$, relative humidity $60-70 \%$, electrical conductivity $1.2 \mathrm{mS} \mathrm{cm}^{-1}$, dissolved oxygen minimum $4 \mathrm{mg} \mathrm{L}^{-1}$, and light intensity around $300 \mu \mathrm{mol} \mathrm{m}^{-2} \mathrm{~s}^{-1}$. The following sections go into further detail on the different environmental parameters to offer a higher resolution analysis of basil production parameters.

Table 3. Environmental needs of basil microgreens grown in a hydroponic system synthesized from the literature review.

\begin{tabular}{|c|c|c|c|}
\hline No. & Parameter & Unit of Measurement & $\begin{array}{l}\text { Average Value of Parameters } \\
\text { (Parameter Variation) }\end{array}$ \\
\hline 1 & Light & $\mathrm{W}$ & 400 \\
\hline 1.1 & Photoperiodicity & $\mathrm{h}$ & $06: 30-21: 30(15 \mathrm{~h})(10-20 \mathrm{~h})$ \\
\hline 1.2 & Light intensity & $\mu \mathrm{mol} \mathrm{m}{ }^{-2} \mathrm{~s}^{-1}$ & $300(200-400)$ \\
\hline 1.3 & Color spectrum & $\mathrm{nm}$ & $440-460(260-780)$ \\
\hline 1.4 & Position & $\mathrm{cm}$ & $\begin{array}{c}\text { 150-Lamps HPS (high-pressure sodium) } \\
\text { 40-Lamps LED }\end{array}$ \\
\hline 2 & Ambient temperature & ${ }^{\circ} \mathrm{C}$ & $21 \pm 2$ day; 17 night \\
\hline 3 & Humidity & $\%$ & $65 \pm 5(50-60)$ \\
\hline 4 & Nutrient & N-P-K: 3-2-3 (\%) & Changed every 10 days \\
\hline
\end{tabular}


Table 3. Cont.

\begin{tabular}{cccc}
\hline No. & Parameter & Unit of Measurement & $\begin{array}{c}\text { Average Value of Parameters } \\
\text { (Parameter Variation) }\end{array}$ \\
\hline 5 & $\mathrm{pH}$ & $\mathrm{pH}$ units & \\
\hline 6 & Electrical conductivity & $\mathrm{mS}$ & 0.4 \\
\hline 7 & Dissolved oxygen & $\mathrm{mg} \mathrm{L}^{-1}$ & \\
\hline 8 & Solution temperature & ${ }^{\circ} \mathrm{C}$ & $20 \pm 2$ \\
\hline
\end{tabular}

\subsubsection{Germination}

For the initial step of successful germination, basil seeds need temperatures in ranges of $20^{\circ} \mathrm{C}$ [54], $23^{\circ} \mathrm{C}$ [55], $25^{\circ} \mathrm{C}$ [56], or even up to $34.5^{\circ} \mathrm{C}$ [57]. In the germination process, seeds follow three distinct phases: water soaking, reinitiating metabolic activities from the seed, appearance of radicle, and subsequent elongation. Factors that influence germination have an important role in all these three phases, and their influence upon each activity helps to determine the germination process. For example, the spectrum of red light favors growth in general, while blue light inhibits growth, but blue light is also a promoter for the germination process [58]. Seed germination is influenced by several other factors as well, such as the water regime, temperature of the media sublayer, light, and hormone balance [59]. For instance, the dipping of seeds into water has shown positive effects on germination [60]. Applying salicylic acid has also been shown to increase the germination capacity of basil seeds under conditions of high salinity [61]. The treatment of seeds with gibberellic, indoleacetic, indolebutyric acid, $\alpha$-naphthyl-acetic acid in concentrations of 50,100, and $150 \mathrm{mg} \mathrm{L}^{-1}$ before germination $\left(25^{\circ} \mathrm{C}\right)$ has also been shown to stimulate germination capacity, with the best results in the case of the gibberellic acid in a concentration of $100 \mathrm{mg} \mathrm{L}^{-1}$ [62]. As seen in Table 4, the time from the start of germination to the appearance of the first radicles varied according to the temperature and the treatment the seeds had undergone [15]. In general, Table 4 demonstrates that the time needed for the appearance of the first radicles decreased inversely with the rise in temperature. Table 4 also shows that the treatment of seeds with gibberellic acid before germination resulted in a reduction in time before radicles appeared in the case of all basil types tested.

Table 4. Days elapsed until the emergence of the first radicles under different temperature and growth hormone treatment [15].

\begin{tabular}{|c|c|c|c|c|c|c|c|c|c|}
\hline \multirow{3}{*}{$\begin{array}{l}\text { Basil } \\
\text { Cultivar }\end{array}$} & \multicolumn{9}{|c|}{ Germinated Seeds at Different Temperatures (\%) } \\
\hline & \multicolumn{3}{|c|}{$10^{\circ} \mathrm{C}$} & \multicolumn{3}{|c|}{$15^{\circ} \mathrm{C}$} & \multicolumn{3}{|c|}{$20^{\circ} \mathrm{C}$} \\
\hline & Control & $\begin{array}{l}\text { Gibberellic } \\
\text { Acid }\end{array}$ & $\begin{array}{l}\text { Ascorbic } \\
\text { Acid }\end{array}$ & Control & $\begin{array}{c}\text { Gibberellic } \\
\text { Acid }\end{array}$ & $\begin{array}{l}\text { Ascorbic } \\
\text { Acid }\end{array}$ & Control & $\begin{array}{c}\text { Gibberellic } \\
\text { Acid }\end{array}$ & $\begin{array}{c}\text { Ascorbic } \\
\text { Acid }\end{array}$ \\
\hline $\begin{array}{c}\text { Aromat de } \\
\text { Buzău }\end{array}$ & - & - & - & 8 & 6 & 7.75 & 3 & 3 & 3.5 \\
\hline Serafim & - & 14 & - & 4.5 & 3.75 & 5 & 2.75 & 2 & 2 \\
\hline $\begin{array}{l}\text { Busuioc } \\
\text { Dulce }\end{array}$ & - & - & - & 5.5 & 3 & 5.25 & 3 & 2 & 2 \\
\hline $\begin{array}{l}\text { Italiano } \\
\text { Classico }\end{array}$ & - & - & - & 4.5 & 3 & 5 & 3 & 2 & 1.75 \\
\hline Dark Opal & - & 11 & - & 4.5 & 3.5 & 4 & 2.75 & 2 & 1.5 \\
\hline Genovese & - & 14 & - & 3.25 & 3 & 5 & 2 & 2 & 2 \\
\hline Grand Verte & - & 13 & - & 3.5 & 3.25 & 4 & 3 & 2 & 2 \\
\hline
\end{tabular}

\subsubsection{Light: Light Intensity, Color Spectrum, Photoperiodism, Position}

There are a few main methods to meet the light requirements of microgreens: the first is to use natural light, although this limits the degree of control, the time of year they can be grown, and the photoperiod; the second is to use artificial light systems such as high-pressure sodium (HPS), fluorescent, or light-emitting diodes (LED), to name a few. Each has its own advantages and disadvantages. However, because of their many advantages, LED artificial lighting systems have recorded the highest growth in the microgreens market segment; this is due to the long lifetime of bulbs $(50,000 \mathrm{~h})$ and that 
they have a power consumption up to $50 \%$ less than fluorescent lamps and up to $80 \%$ lower than the incandescent ones while achieving comparable, and even in some cases superior, outputs [1]. However, their initial upfront cost can be prohibitive for consumer use. Another advantage of LEDs is the low amount of heat produced from the lights, which avoids burning the young seedlings and allows variable light distance setups. HPS lights are more common for mature vegetative use, given their high heat load and spectra; they are also more expensive over time given their high electricity cost. Fluorescent lights are cheap, but they lack spectral outputs and intensity. Furthermore, disposing of them can be toxic and costly, given their material composition.

Microgreens are, in general, very sensitive to light, and the most important aspects that influence them are:

- Light intensity, which is a quantitative measure that refers to the number of photons that reach the leaf level during a unit of time $\left(\mu \mathrm{mol} \mathrm{m} \mathrm{m}^{-2} \mathrm{~s}^{-1}\right)$. This is the most important parameter for the photosynthetic process. Upon the placement of lamps, one should consider their type and the fact that light intensity is reduced by the square of distance [63]. Different types of lamps also produce variable amounts of heat, which necessitates a certain distance from the young vulnerable microgreens;

- Spectral distribution of light is the wavelength of light that the plants are exposed to. For photosynthesis, plants respond best to red and blue light spectra (300-450 nm for blue, 620-750 for red). However, new research is pinpointing that photomorphogenesis occurs when plants, including microgreens, are exposed to wavelengths outside the traditional range: for instance, it has been shown that plants respond to UV light, in the range of 260-400, and to far-red light, from 750 to 780; this photomorphogenesis results in higher accumulations of specific phytochemicals and nutrients that improve the flavor and health benefits of microgreens [64-68];

- Photoperiodism, which refers to the lighting duration, has the most relevance for inciting phenological stages, such as blooming. According to the crop species, the generative phase can be controlled by manipulating photoperiodism [69]. It is, therefore, appropriate to have a long photoperiod for increased photosynthesis as well as ensuring the microgreens do not become cued to a more autumnal day length.

All three light aspects are involved with the production and accumulation of active substances in the basil plant (Table 5). Recent studies on systems of artificial lighting have shown that even the quality of light and light spectrum can influence plants significantly. For instance, the spectrum of blue color (including UV A and B ranges) can stimulate the production of secondary metabolites, while red spectra (including far-red) influences plant growth and the accumulation of saccharides (starch and sugars) [65-68]. In this vein, Ying et al. [69] suggest that the combination of $15 \%$ blue and $85 \%$ red LED light can potentially replace cool white fluorescent light as the sole light source for indoor production of microgreens. Furthermore, the use of white light has been shown to result in a short hypocotyl, while red light made stems elongate, and blue light helped with the accumulation of biomass [1]. Samuoliene et al. [70] evaluated the impact of additional red LED lighting, in the short run, on the production of antioxidants in microgreens. At the pre-harvest stage of 3 days, HPS lamps were supplemented by $638 \mathrm{~nm}$ LEDs, whereas reference plants continued under lighting conditions identical to those of the growth stage. Photosynthetic photon flux density (PPFD) generated by lighting was $170 \mu \mathrm{mol} \mathrm{m}^{-2} \mathrm{~s}^{-1}$, and net PPFD generated by lighting in combination with HPS lamps was $300 \mu \mathrm{mol} \mathrm{m} \mathrm{m}^{-1}$ (16-h; 19-22/15-18 ${ }^{\circ} \mathrm{C}$ ). Under these conditions (mild photooxidative stress), for basil microgreens, the concentration of phenols grew by $30.7 \%$, the antioxidant compounds increased by $18.3 \%$, the total anthocyanin wasn't influenced, and the content of ascorbic acid decreased 53.9\%. Another study showed that HPS lighting recorded a significantly lower quantity of oxygen in the nutritional solution compared to LED lighting [1]. These studies all demonstrate the tradeoffs associated with different types, qualities, and quantities of light when producing microgreens. 
Furthermore, the use of different qualities and quantities of light can also be used to augment other plant production processes. For instance, there are several studies that demonstrated the influence of light on the germination process. It has been shown that light intensity has no influence on the germination of seeds [71], but what does influence germination is the light wavelength $[72,73]$. This sensitivity to light separates seeds into three categories: seeds that need light in order to germinate, seeds that need darkness in order to germinate, and seeds that are neutral to light [74]. Reaction to light has also been analyzed at a genetic level in order to observe what genes activate in the presence of light and what biochemical processes are at the basis of synchronizing with the best season in which the plant must be active [75]. For instance, there are a series of photoreceptors that determine how plants react to light: phytochromes that regulate seed germination, coordinate the development of hypocotyl and roots, and cryptochromes that inhibit stem elongation, control the initiation of blooming according to photoperiodism, regulate circadian rhythm, phototropism, and stomatal conductance [76]. As plants absorb blue and red light and reflect green light, current technology allows us to use a specific artificial lighting system with targeted wavelength spectra that are beneficial for plant photosynthesis while reducing power consumption. These LEDs can be manipulated so as to apply the recipe of light adequate for the specific crop species.

Table 5. Studies on light spectrum, intensity, and photoperiod combinations on basil growth and yields.

\begin{tabular}{|c|c|c|c|c|}
\hline No. & Crop & Treatments & Effects & Reference \\
\hline 1 & $\begin{array}{c}\text { Basil, } \\
\text { Ocimum } \\
\text { basilicum L., } \\
\text { sweet basil }\end{array}$ & $\begin{array}{l}\text { Three treatments: only white } \\
\text { LED (W); combination of blue } \\
\text { and red LED (BR) }(84 \% \mathrm{R}, 16 \% \\
\text { B); combination of red (R), blue } \\
\text { (B) and far-red (F) LED (BRF) } \\
\text { (79\% R, } 11 \% \text { B, and } 10 \% \mathrm{~F}) ; \\
\text { PPFD was set at } 155 \mu \mathrm{mol} \mathrm{m} \mathrm{m}^{-2} \mathrm{~s}^{-1} \text {; } \\
\text { photoperiod: } 20 \mathrm{~h}\end{array}$ & $\begin{array}{l}\text { Combination of blue (B), red (R), and far-red (F) LED } \\
\text { illumination led to a one-fold increase in the yield in } \\
\text { comparison with only white LED illumination (W); } \\
\text { on the other hand, the use of blue (B) and red (R) } \\
\text { LED illumination resulted in a half-fold increase in } \\
\text { plant yield; the results of this study demonstrated the } \\
\text { commercial viability of both BRF-, and BR- } \\
\text { illuminated grow tents compared to the commonly } \\
\text { used W-illuminated counterparts }\end{array}$ & [77] \\
\hline 2 & $\begin{array}{c}\text { Basil, } \\
\text { Ocimum basilicum L., } \\
\text { Sweet Genovese, } \\
\text { and Red Rubin }\end{array}$ & $\begin{array}{l}\text { Different ratios of LED blue } \\
\text { and red illumination; } 4 \text { light } \\
\text { treatments were } 100 \% \text { white } \\
\text { (White) and various red (R) to } \\
\text { blue (B) ratios, as follows: } \\
\text { 2R:1B, 1R:1B, and 1R:2B, } \\
\text { intensities }\end{array}$ & $\begin{array}{l}\text { Growth was enhanced with predominantly blue } \\
\text { illumination, leading to larger cotyledon area and } \\
\text { higher fresh mass. The same treatment elevated } \\
\text { chlorophyll a and anthocyanin pigments contents. } \\
\text { Stimulation of phenolic synthesis and free radical } \\
\text { scavenging activity was improved by predominantly } \\
\text { red light in the green cultivar and by predominantly } \\
\text { blue light in the red cultivar }\end{array}$ & {$[68]$} \\
\hline 3 & $\begin{array}{c}\text { Basil, } \\
\text { Ocimum } \\
\text { basilicum } \text { L., } \\
\text { Sweet Genovese }\end{array}$ & $\begin{array}{l}\text { LED's blue } 447 \mathrm{~nm} \text {, red } 638-665 \mathrm{~nm} \text {, } \\
\text { and far-red } 731 \mathrm{~nm} \\
\text { from increased or } \\
\text { supplemental red light. PPFD } \\
\text { was set to } 231 \text { during growth, up to }^{-2} \mathrm{~s}^{-1} \text { during } \\
300 \mu \mathrm{mol} \mathrm{m}^{-2} \mathrm{~s}^{-} \text {. } \\
\text { 3-day treatment changing R638 } \\
\text { or R665 PPFD level; } 16 \mathrm{~h} \text { photoperiod }\end{array}$ & $\begin{array}{l}\text { The treatments significantly increased contents of } \\
\text { phenolics, beta-tocopherol, ascorbic acid, and DPPH } \\
\text { (1,1-diphenyl-2-picrylhydrazyl) center dot, an } \\
\text { indicator of antioxidant capacity, but suppressed } \\
\text { accumulation of lutein and beta-carotene; under } \\
\text { supplemental or increased red } 638 \text { nm light, amounts } \\
\text { of tested antioxidants were greater }\end{array}$ & [78] \\
\hline 4 & $\begin{array}{c}\text { Basil, } \\
\text { Ocimum } \\
\text { basilicum L., } \\
\text { Sweet Genovese }\end{array}$ & $\begin{array}{l}\text { Supplemental } 520 \text { and } 622 \mathrm{~nm} \\
\text { lighting; supplemental 366- } \\
\text { and } 390 \mathrm{~nm} \text { UV-A radiation; } \\
\text { lighting with high PPFD level } \\
\text { of red (638 nm) LEDs; } 16 \mathrm{~h} \text { photoperiod }\end{array}$ & $\begin{array}{l}\text { Supplemental } 520 \text { and } 622 \mathrm{~nm} \text { lighting was more } \\
\text { efficient for nitrate reduction, while the antioxidative } \\
\text { system indices were enhanced by } 595 \mathrm{~nm} \text { diodes; } \\
\text { supplemental } 366 \text { and } 390 \mathrm{~nm} \text { UV-A radiation were } \\
\text { more favorable for antioxidant accumulation; short- } \\
\text { term (3-days before harvesting) lighting with high } \\
\text { PPFD level of red ( } 638 \mathrm{~nm} \text { ) LEDs increased the } \\
\text { amounts of the secondary metabolites of microgreens }\end{array}$ & [79] \\
\hline 5 & $\begin{array}{c}\text { Purple-leaf, } \\
\text { Dark opal, } \\
\text { and green-leaf Sweet } \\
\text { Genovese forms of } \\
\text { Ocimum basilicum L. }\end{array}$ & $\begin{array}{c}\text { The main lighting system (HPS } \\
\text { lamps and natural daylight) was } \\
\text { supplemented with } \sim 13.0 \mu \mathrm{mol} \mathrm{m} \mathrm{m}^{-2} \mathrm{~s}^{-1} \\
\text { flux of UV-A } 390 \\
\text { nm blue light, and total PPFD } \\
\text { was } \sim 125 \mu \mathrm{mol} \mathrm{m}^{-2} \mathrm{~s}^{-1}(16 \mathrm{~h} \\
\text { photoperiod) for } 1 \text { or } 7 \text { days } \\
\text { before harvest, or entire } \\
\text { growth period, } 14 \text { days }\end{array}$ & $\begin{array}{l}\text { UV-A enhanced antioxidant properties in green-leaf. } \\
\text { Generally, UV-A irradiation for } 7 \text { days significantly } \\
\text { inhibited growth and hypocotyl elongation of } \\
\text { green-leaf, and for } 14 \text { days of both varieties. The total } \\
\text { phenols and anthocyanin contents significantly } \\
\text { decreased after } 1 \text { day UV-A irradiation in purple-leaf } \\
\text { basils, with continuous decrease following UV-A } \\
\text { irradiation for } 7 \text { or } 14 \text { days being shown. No } \\
\text { significant differences in leaf chlorophyll index } \\
\text { were determined }\end{array}$ & [80] \\
\hline
\end{tabular}




\subsubsection{Air and Water Temperature}

Besides the major factors discussed above, there are other environmental factors that have more subtle effects on basil microgreen production that should be considered as well. For instance, the temperature of the nutritional solution is generally a few degrees lower than that of the environment, which influences the content of oxygen in the water, which is essential for root and plant physiological functioning and health [81]. For basil, the nutritional solution must be maintained at a low temperature (under $20^{\circ} \mathrm{C}$ ) in order to maintain the quantity of oxygen dissolved in water under optimal parameters $\left(6.5 \mathrm{mg} \mathrm{L}^{-1}\right)$ [1]. There are several factors that affect solution temperature. For instance, the water that is returned via recirculating hydroponic systems is usually warmer than the water that is freshly introduced into the system, which creates a challenge for ensuring the best dose of oxygen dissolved in water, according to Waller and Yitayew [82]. The temperature of the nutritional solution must therefore be controlled and corrected while also considering the demands of each crop. This is because the temperature of the solution also influences the assimilation of nutritional elements; for instance, at low temperatures, the assimilation of nitrogen drops (the accumulation of phosphorus and potassium is less affected). Furthermore, artificial light has an indirect effect on the oxygen dissolved in water through the heat emanated by the different lamps that in turn influence the temperature of the nutritional solution in the water. In a hydroponic system, the oxygen dissolved in water is in the optimal range when the temperature of the solution is between 15 and $27^{\circ} \mathrm{C}[1]$.

In general, it is also important to consider these optimal thermal ranges for air temperature as well as water, as it impacts other physiological processes; for instance, when the temperature exceeds $30^{\circ} \mathrm{C}$, basil can suffer from thermal stress. This is important to incorporate into production designs, as temperature influences stomatal conductance, photosynthesis, and the growth and development of plants [83]. Furthermore, certain bioactive substances become more concentrated during temperature ranges that are not in the best parameters for cultivating, while others drop under the same conditions. In the opposite direction, thermal stress with temperatures under the normal range $\left(18^{\circ} \mathrm{C}\right)$ can determine a slowdown or even the stagnation of growth, in the case of certain thermophilic plants. In general, basil prefers temperatures between 18 and $27^{\circ} \mathrm{C}$, with a lack of growth and subsequent radicle emergence response in cooler conditions. Basil does not tolerate cool weather during its vegetative growth stage, as the plant development slows down, and it can be damaged at temperatures between 0 and $1^{\circ} \mathrm{C}[34,39]$. These thermal ranges and outcomes can be harnessed to achieve desirable microgreen production during different phenological stages while also maximizing their desirable outputs.

\subsubsection{Relative Humidity}

Controlling the relative humidity $(\mathrm{RH})$ is important for ensuring optimal functioning of the plant by helping to ensure a correct nutrition uptake and profile, reducing drought stress through excessive transpiration, and controlling pathogenic microorganism activity. Atmospheric humidity is directly related to air temperature, which depends, among other things, on air composition. For instance, at $5{ }^{\circ} \mathrm{C}$, saturated air contains $6.8 \mathrm{~g} \mathrm{~m}^{-3}$ water that reaches $17.4 \mathrm{~g} \mathrm{~m}^{-3}$ at $20^{\circ} \mathrm{C}$. In the case of a sudden drop in temperature, air sheds water, and condensation appears, i.e., gas liquefaction with water droplet formation. In general, the ideal value of $\mathrm{RH}$ for temperate plants is $50-60 \%$, and for tropical plants, it is $70-90 \%$. For basil, the ideal RH is approximately $60-70 \%$ at a constant temperature of $22{ }^{\circ} \mathrm{C}$ [1]. Moving beyond this RH range can lead to microbial spoilage of the plants, with a very likely incidence of mold or other pathogens. There are a few key factors that can augment or diminish RH in hydroponic systems; for instance, the type of water delivery system, such as aeroponics, which can acutely increase RH. Another example is via temperature changes from the type of lighting system used, such as HPS lights, which will increase the temperature and therefore lower RH. Proper ventilation can also greatly influence the RH and likelihood of pathogenicity by correcting the amount of humidity in the air. 
Simple fans in this regard can effectively distribute air and wick moisture directly off the microgreen leaves. Another example of exogenous factors that can influence $\mathrm{RH}$ is $\mathrm{CO}_{2}$ concentration, which can augment temperature and lead to the accumulation of humidity and thereby increase the humidity in a room. This is important to consider for systems that have added $\mathrm{CO}_{2}$ to improve plant photosynthetic capacity.

\subsubsection{Dissolved Oxygen}

Dissolved oxygen in water is an important parameter for the optimal functioning of the nutritional solution in hydroponic systems. It influences the respiration of the radicular system and its capacity to extract micro- and macro-elements [84]. Moreover, a reduction in the quantity of oxygen from the water can lead to a reduced conductivity of the leaf's stomata [85], which can impact photosynthesis, thus affecting the growth and development of the plant species [86]. Low levels of oxygen in the water can also be detrimental to root growth and incite the colonization of anaerobic microbes. Although oxygen can be enriched by applying peroxide, this can chemically alter the nutritional solution as a consequence. Furthermore, this parameter has some dynamics that are hard to anticipate, as it is influenced by several biotic and abiotic factors [87]. However, it has been noted in the literature that the concentration of oxygen dissolved in water of over $6 \mathrm{mg} \mathrm{O}_{2} \mathrm{~L}^{-1} \mathrm{~min}^{-1}$ prevents the development of diseases in the nutritional solution [88]. Furthermore, oxygen dissolved in water has a deterministic effect on the growth and development of plants, but also in the accumulation of bioactive substances; for basil, it is recommended to be $6.5 \mathrm{mg} \mathrm{L}^{-1}$ [1]. Therefore, controlling the oxygen levels is essential for successfully achieving desired microgreen production outputs without having to undertake remedial solutions for disease burdens or setbacks due to low growth trajectories.

\subsubsection{The Nutrient Solution}

In hydroponic systems, the nutrient solution must be carefully monitored by checking certain essential parameters such as $\mathrm{pH}$, electrical conductivity, specific nutrient quantities, dissolved oxygen, and temperature, as well as qualitative factors such as algae presence or other microorganism activity. In addition to other parameters, the nutrient solution has a very important role in ensuring successful seed germination [89]. Beyond this, the nutritional solution has an important role in the growth and development of plants, but if done incorrectly, can also lead to chemical stress, which can be diagnosed in a variety of ways [90]. One example of this chemical stress is when nitrogen, in excess, slows down water absorption and causes dysfunctional growth and photosynthesis. This can be identified via the observation of yellowed leaves, for instance.

In the case of hydroponic systems, one must take into consideration the ratio of macroand microelements from the nutritional solution. An adequate nutrient solution used in hydroponics must contain nitrogen, potassium, phosphorus, calcium, magnesium, sulfur, iron, manganese, copper, zinc, molybdenum, boron, and chlorine. These have a direct effect on the primary and secondary metabolism of the plant, which influences the health and downstream quality of products. Gaseous elements, such as oxygen and carbon dioxide, also significantly influence the secondary metabolism of plants. Oxygen and carbon dioxide have an essential role in photosynthesis and transpiration, which influences the accumulation of active substances in plants.

The nutrient solution is the ideal environment to facilitate more effective standardization of food quality and helps assure the safety of the food product that is eventually offered to the consumer [9]. The adequate biofortification of plants with appropriate nutrition can help ensure both health and quality, as well as buffering against decay and microbial spoilage. For example, among the various biofortification techniques, selenium application in the nutrient solution of hydroponic systems has been shown to be effective. This is important because selenium is considered essential for human nutrition as it is involved in the metabolic pathway of selenoproteins and relevant biological functions [9]. By using the technique of liquid absorption, selenium presence in the environment is minimized, 
and selenium assimilation is maximized by the absence of soil interactions; moreover, the constant root exposure to the nutrient solution affords the application of reduced selenium rates for adequate uptake compared to plants in soil systems. Calcium chloride biofortification has also shown promising results on increasing microgreen nutrient and phytochemical presence, which increases their value for human consumption [13].

\subsection{7. $\mathrm{pH}$}

In general, basil prefers a $\mathrm{pH}$ between 6 and 7. However, the optimal ranges of $\mathrm{pH}$ for the production of basil are different compared to conventional systems that are planted in the soil. For hydroponic systems, the $\mathrm{pH}$ must be between 5.5 and 7, in which case the radicular system has macro and microelements available in the nutritional solution, which are necessary for plant development. The $\mathrm{pH}$ and electrical conductivity are parameters that can be corrected by the nutritional solution [91], as well as through the addition of buffer solutions that can augment or diminish $\mathrm{pH}$. These are widely available and simple to use, ensuring that this parameter is both relatively easy to measure with affordable instruments and also easily corrected via solution buffering.

\subsubsection{Electrical Conductivity (EC)}

The optimal electrical conductivity range for a nutrient solution depends on the species cultivated and on the developmental stage of the plants. Seedlings must initially be fertilized with a solution with an electrical conductivity of $1.2 \mathrm{mS}$ as a maximum, with its concentration growing progressively with the development of plants. Electrical conductivity has no influence on the pathogens that can develop in the solution, although optimal nutritional fortification is important for plant immune functioning, and chemical corrections can be made to control pests. For example, the use of potassium silicate can control pathogens such as Fusarium spp. [92]. Therefore, controlling electrical conductivity is essential for ensuring an adequate supply of molecular building blocks for growth, and thereby buffering the plant against pests and completing the desired microgreen production in a timely manner.

Table 6 describes nine different examples from the literature on the impact of different treatments of the $\mathrm{pH}, \mathrm{EC}$, substrate, and nutrient solution on downstream outcomes of basil microgreen production.

Table 6. Studies on effects of nutrient solution, $\mathrm{pH}, \mathrm{EC}$, and substrate on basil growth and production.

\begin{tabular}{|c|c|c|c|c|}
\hline No. & Reference & Investigation Context & Treatment & $\begin{array}{l}\text { Results (Yield, Quality, and Quantity, } \\
\text { Chlorophyll, etc.) }\end{array}$ \\
\hline 1 & [93] & $\begin{array}{l}\text { Influence of three growing } \\
\text { media (vermiculite, coconut } \\
\text { fiber, and jute fabric) on yield } \\
\text { and quality parameters of two } \\
\text { varieties (green and red) }\end{array}$ & $\begin{array}{l}\text { Microgreens were grown } \\
\text { in a floating micro } \\
\text { experimental growing } \\
\text { system equipped with } \\
\text { LED lamps, with } \\
\text { modulation of both } \\
\text { quantity and spectra of the light }\end{array}$ & $\begin{array}{l}\text { Results showed high yield, comprised from } \\
2 \text { to } 3 \mathrm{~kg} \mathrm{~m}^{-2} \text {, and nutritional quality varied } \\
\text { among species, and higher antioxidant } \\
\text { compounds were found in red basil on } \\
\text { vermiculite and jute; coconut fiber allowed } \\
\text { the differentiation of crop performance in } \\
\text { terms of sucrose and above all nitrate; the } \\
\text { choice of the substrate significantly affected } \\
\text { the yield, the dry matter percentage, and } \\
\text { the nitrate concentration }\end{array}$ \\
\hline 2 & [94] & $\begin{array}{l}\text { Influence of substrate: nutrient } \\
\text { film technique (NFT) culture } \\
\text { compared with conventional } \\
\text { soil culture and compost mixed } \\
\text { coco-peat substrate }\end{array}$ & $\begin{array}{l}\text { The treatments were: top } \\
\text { soil (control; T1) as } \\
\text { compost and coir dust } \\
\text { mixture at the rate of } 1: 1 \\
\text { (T2) and NFT (T3); the } \\
\text { pH and EC of the supply } \\
\text { solution were } 5.9 \text { (at } 27.9^{\circ} \mathrm{C} \text { ) and } \\
1.5 \mathrm{mS} \mathrm{cm}^{-1} \text {, respectively }\end{array}$ & $\begin{array}{l}\text { A significantly high vegetative growth and } \\
\text { total yield was found in the NFT; the } \\
\text { nitrate accumulation was well below the } \\
\text { maximum permissible limit (MPL), set } \\
\text { forth by the recommendations of the } \\
\text { European Health Commission }\end{array}$ \\
\hline 3 & [9] & $\begin{array}{c}\text { Identification and quantification } \\
\text { of polyphenols, major } \\
\text { carotenoids, and macro/micro-minerals; } \\
\text { twenty-seven phenolic } \\
\text { compounds were quantified, of } \\
\text { which the most abundant were: } \\
\text { cichoric acid and rosmarinic }\end{array}$ & $\begin{array}{c}\text { Sodium selenate } \\
\text { applications at three } \\
\text { concentrations }(0,8 \text {, and } \\
16 \mu \mathrm{M} \mathrm{Se}) \text { on green and } \\
\text { purple basil; Hoagland } \\
\text { nutrient solution was } \\
\text { used, and they used a } \\
\text { pH: } 6 \text { and EC: } 0.35 \mathrm{dS} \mathrm{cm}^{-1}\end{array}$ & $\begin{array}{l}\text { In green and purple varieties, the } 8 \mu \mathrm{M} \text { Se } \\
\text { application enhanced the lutein } \\
\text { concentration by } 7 \% \text { and } 19 \% \text {, } \\
\text { respectively; the same application rate also } \\
\text { increased the overall macroelement } \\
\text { content by } 35 \% \text { and total polyphenols } \\
\text { concentration by } 32 \% \text { but only in the } \\
\text { green; the latter had a tripled chicoric acid } \\
\text { content compared to the untreated control }\end{array}$ \\
\hline
\end{tabular}


Table 6. Cont.

\begin{tabular}{|c|c|c|c|c|}
\hline No. & Reference & Investigation Context & Treatment & $\begin{array}{l}\text { Results (Yield, Quality, and Quantity, } \\
\text { Chlorophyll, etc.) }\end{array}$ \\
\hline 4 & [95] & $\begin{array}{l}\text { Selenium biofortified } \\
\text { microgreens from selenium- } \\
\text { enriched seeds; substrate: } \\
\text { perlite and vermiculite with a } \\
\text { pH: } 5.6 \text { and EC: } 2.04 \mathrm{dS} \mathrm{m}^{-1}\end{array}$ & $\begin{array}{l}\text { Grown in a nutrient } \\
\text { solution containing } 0 \\
\text { (control), } 4 \text { or } 8 \mathrm{mg} \mathrm{Se} \mathrm{L}^{-1} \\
\text { as sodium selenate }\end{array}$ & $\begin{array}{l}\text { Seeds from plants treated with Se showed a } \\
\text { significantly higher germination index than } \\
\text { seeds from control plants, and the } \\
\text { microgreens retained the Se; the antioxidant } \\
\text { capacity of Se-fortified microgreens was } \\
\text { higher compared to the control }\end{array}$ \\
\hline 5 & [96] & $\begin{array}{l}\text { Effect of salinity on biomass } \\
\text { yield; for every } 10 \mathrm{mM} \text { increase } \\
\text { in } \mathrm{NaCl} \text {, treatment solution } \mathrm{EC} \\
\text { increased } 1.1 \mathrm{dS} \mathrm{m}^{-1} ; \mathrm{pH}: 5.1-5.2 \text {; } \\
\text { hydroponic solution } \mathrm{pH} \\
\text { decreased slightly during the } \\
\text { experiment (7.5 to } 6.8 \text { ), but all } \\
\text { treatments had similar } \mathrm{pH}\end{array}$ & $\begin{array}{l}\text { Two cultivars were } \\
\text { grown hydroponically } \\
\text { for } 71 \mathrm{~d} \text { with four } \\
\text { different concentrations } \\
\text { of } \mathrm{NaCl}(\text { no NaCl, low, } \\
\text { moderate, and high } \\
\left.\left(20 \mathrm{dS} \mathrm{m}^{-1}\right)\right)\end{array}$ & $\begin{array}{l}\text { In both cultivars, salinity increased leaf } \\
\text { concentrations of certain caffeic acid } \\
\text { derivatives, caftaric acid, cinnamyl malic } \\
\text { acid, and feruloyl tartaric acid and } \\
\text { decreased concentrations of chicoric acid; } \\
\text { salinity increased leaf concentrations of } \\
\text { the two of the major polyphenolics, } \\
\text { quercetin-rutinoside, and rosmarinic acid; } \\
\text { salinity decreased concentrations of } \\
\text { rosmarinic acid in leaves }\end{array}$ \\
\hline 6 & [10] & $\begin{array}{l}\text { Yield, mineral uptake, and } \\
\text { quality were measured, among } \\
\text { other outputs }\end{array}$ & $\begin{array}{c}\text { Hoagland's nutrient } \\
\text { solution; } \mathrm{pH} \text { : } 5.56 \text {; } \mathrm{EC} \text { : } \\
1.12 \mathrm{dS} \mathrm{cm}^{-1} \text {; minimum } \\
\text { and maximum } \\
\text { temperatures: } 9.7-43.1^{\circ} \mathrm{C} \text {; microgreens } \\
\text { were harvested at the first true } \\
\text { leaf stage, with green } \\
\text { and swollen cotyledons }\end{array}$ & $\begin{array}{l}\text { Results showed high concentrations of } \\
\text { some minerals, but their nutrient uptake } \\
\text { was limited due to low yield; nitrates } \\
\text { content was lower if compared with that } \\
\text { usually measured in baby leaf or adult } \\
\text { vegetables of the same species, as well as } \\
\text { the concentration of chlorophylls, } \\
\text { carotenoids, phenols, and sugars }\end{array}$ \\
\hline 7 & [97] & Nutritional dynamics & $\begin{array}{l}\text { Compared between } \\
\text { aquaponic and } \\
\text { hydroponic systems } \\
\text { using crayfish } \\
\text { (Procambarus spp.) as } \\
\text { the aquatic species }\end{array}$ & $\begin{array}{c}\text { Aquaponic (AqB) showed } 14 \%, 56 \% \text {, and } \\
65 \% \text { more height, fresh weight, and dry } \\
\text { weight, respectively, compared to } \\
\text { hydroponic (HyB) }\end{array}$ \\
\hline 8 & [98] & $\begin{array}{l}\text { Quantify productivity and } \\
\text { characterize growth of } 35 \text { cultivars } \\
\text { grown in two hydroponic } \\
\text { production systems }\end{array}$ & $\begin{array}{l}\text { In this study, two } \\
\text { hydroponic systems } \\
\text { were compared: nutrient } \\
\text { film technique (NFT) } \\
\text { and deep flow technique } \\
\text { (DFT) systems, grown } \\
\text { for } 3 \text { weeks }\end{array}$ & $\begin{array}{l}\text { Fresh weight of plants grown in DFT } \\
\text { systems was } 2.6 \text { g greater compared with } \\
\text { plants grown in NFT systems. Cultivars } \\
\text { differed greatly in fresh weight; however, } \\
\text { the yield seems to be affected more by } \\
\text { cultivar selection than hydroponic } \\
\text { production system }\end{array}$ \\
\hline 9 & [99] & $\begin{array}{c}\text { The nutrient solutions } \\
\text { contained different } \mathrm{NO}_{3}^{-} \\
\text {concentrations }\left(0.5,5.0 \text { and } 10.0 \mathrm{~mol} \mathrm{~m}^{-3}\right) \\
\text { or } \mathrm{NO}_{3}-/ \mathrm{NH}_{4}{ }^{+} \text {molar } \\
\text { ratios }(1: 0,1: 1 \text { and } 0: 1 ; \text { total } \mathrm{N} \\
\text { concentration was } 10.0 \text { mol m } \\
\text { concentration of other nutrients } \\
\text { core } \\
\text { were as follows: } 1.0 \text { mol m} \mathrm{m}^{-3} \mathrm{P}- \\
\mathrm{H}_{2} \mathrm{PO}_{4}, 10.0 \mathrm{~mol} \mathrm{~m}^{-3} \mathrm{~K}^{+} ; 3.0 \mathrm{~mol} \mathrm{~m}^{-3} \\
\mathrm{Ca}^{2+} ; 1.5 \mathrm{~mol} \mathrm{~m}^{-3} \mathrm{Mg}^{2+} \text { plus } \\
\text { trace elements }\end{array}$ & $\begin{array}{l}\text { Influence of nitrogen } \\
\text { nutrition on growth and } \\
\text { accumulation of } \\
\text { rosmarinic acid }\end{array}$ & $\begin{array}{l}\text { The use of a total } \mathrm{NO}_{3}^{-} \text {concentration of } \\
5 \text { mol m}{ }^{-3} \text { resulted in optimal plant growth } \\
\text { and rosmarinic acid production; this } \\
\text { suggests that the standard } \mathrm{N} \text { concentration } \\
\text { used in hydroponic culture ( } 10 \text { mol } \mathrm{m}^{-3} \text { or } \\
\text { higher) could be reduced considerably, } \\
\text { with important implications from the } \\
\text { environmental point of view; in contrast, } \\
\text { the addition of } \mathrm{NH}_{4}^{+} \text {to the nutrient } \\
\text { solution was detrimental to both growth } \\
\text { and rosmarinic acid production }\end{array}$ \\
\hline
\end{tabular}

\section{Conclusions}

The literature review undertaken here has demonstrated that the production of basil microgreens using hydroponic systems must be organized with care for controlling the many environmental and production parameters to achieve desired outputs that are of adequate quality. This is in comparison to more conventional production methods using soil, considering all the controllable factors in hydroponic systems that have been shown to influence the accumulation of bioactive substances, the harvest timeframe, and the quality of the finished product. Furthermore, the lack of a soil's microbiome in hydroponic systems is also important to consider, as unsuccessful parameterization leaves the plants vulnerable to harmful spoilage by microorganisms. However, the high degree of environmental control necessary for optimal growth can also be beneficial to hydroponic systems, as the sophisticated organization can lead to the elaboration of certain protocols to influence factors that can positively influence plants in order to obtain a crop as uniform as possible throughout the year, with higher concentrations of active substances and nutrients valuable for human health. This is why it is necessary to standardize certain cultivation protocols to ensure their quality; this is also why future research will benefit from syntheses of a wide variety of data on the value and production trends of hydroponically grown basil 
microgreens. For instance, there is a wide variation of environmental impact factors and their relationship to downstream basil outputs, which means that there is no single prescription that will guarantee perfect results. Despite this, the literature review undertaken here has demonstrated that there are optimal ranges within which one can begin the task of designing effective prescriptions for successful microgreen production.

This paper has shown that the nutritional solution, temperature, and light regime have the most important role in seed germination and development while also summarizing the recent research on the many promising research trends in refining microgreen production to achieve optimal outputs along its phenological stages. The nutritional solution, air, and water temperature, light regime, $\mathrm{pH}$, electrical conductivity, dissolved oxygen, $\mathrm{CO} 2$ concentration, and relative humidity are all important factors that influence secondary metabolism from an incipient phase, which in the final stages increases both the perceived and actual value of the plants by contributing to human health and nutritional fortification. This literature review has shown that microgreen producers must integrate specific systematic hydroponic strategies to obtain high-quality microgreens and high quantity and quality bioactive substances while also avoiding the potential for spoilage and low-quality production when moving too far beyond the noted parameter ranges summarized here. Many authors in the literature review have noted that best practices have not been developed; this literature review has therefore gathered critical information regarding hydroponically grown basil microgreen production that can be used by researchers and producers to improve the chances of a successful production of yields and valuable secondary metabolites.

Author Contributions: T.R.: conceptualization; writing-original draft preparation; supervision; project administration; funding acquisition. R.J.C.: conceptualization; writing-review and editing; P.I.M.: writing - review and editing; resources; data curation. M.A.M.: investigation; data curation. B.B.G.: conceptualization; review and editing; supervision. All authors have read and agreed to the published version of the manuscript.

Funding: This work was jointly supported by (i) grant of the Romanian National Authority for Scientific Research and Innovation, CCCDI-UEFISCDI, project number COFUND-ICT-AGRI-FOODGOHYDRO-2, within PNCDI III in Romania and by (ii) Green Development and Demonstration Program, under The Ministry of Food, Agriculture and Fisheries of Denmark within the framework of GOHYDRO project (journal number: 34009-20-1815). GOhydro is part of the ERA-NET Cofund ICTAGRI-FOOD with funding provided by national sources, Executive Agency for Higher Education, Research, Development and Innovation Funding, and co-funding by the European Union's Horizon 2020 research and innovation program, grant agreement number 862665 .

Institutional Review Board Statement: Not applicable.

Informed Consent Statement: Not applicable.

Data Availability Statement: No new data were created or analyzed in this study. Data sharing is not applicable to this article. Any quoted data can be checked in their respective published reference listed below.

Conflicts of Interest: The authors declare no conflict of interest.

\section{References}

1. Giurgiu, G.M. Research on Hydroponic Cultivation of Some Medicinal and Aromatic Plant Species and the Influence of the Technology on the Bioactive Substance. Ph.D. Thesis, USAMV Cluj-Napoca, Cluj-Napoca, Romania, 2016.

2. De Vries, G. Feeding the world in the 21st century. Trends Plant. Sci. 2000, 5, 190. [CrossRef]

3. Khazaie, H.R.; Nadjafi, F.; Bannayan, M. Effect of irrigation frequency and planting density on herbage biomass and oil production of thyme (Thymus vulgaris) and hyssop (Hyssopus officinalis). Ind. Crop. Prod. 2008, 27, 315-321. [CrossRef]

4. Chen, F.; Tang, Y.N.; Shen, M.Y. Coordination control of greenhouse environ-mental factors. Int. J. Autom. Comput. 2011, 8, 147-153. [CrossRef]

5. Ncube, B.; Finnie, J.F.; Van Staden, J. Quality from the field: The impact of environmental factors as quality determinants in medicinal plants. S. Afr. J. Bot. 2012, 82, 11-20. [CrossRef] 
6. Tawaha, A.A.; Karaki, G.A.; Adnan, M. Antioxidant activity, total phenols and variation of chemical composition from essential oil in sage (Salvia officinalis L.) grown under protected soilless condition and open field conditions. Adv. Environ. Biol. 2013, 7, 894-901.

7. Lee, J.S.; Pill, W.G.; Cobb, B.B.; Olszewski, M. Seed treatments to advance greenhouse establishment of beet and chard microgreens. J. Hortic. Sci. Biotechnol. 2004, 79, 565-570. [CrossRef]

8. Xiao, Z.; Lester, G.E.; Luo, Y.; Wang, Q. Assessment of vitamin and carotenoid concentrations of emerging food products: Edible microgreens. J. Agric. Food Chem. 2012, 60, 7644-7651. [CrossRef] [PubMed]

9. Pannico, A.; El-Nakhel, C.; Graziani, G.; Kyriacou, M.C.; Giordano, M.; Soteriou, G.A.; Zarrelli, A.; Ritieni, A.; De Pascale, S.; Rouphael, Y. Selenium biofortification impacts the nutritive value, polyphenolic content, and bioactive constitution of variable microgreens genotypes. Antioxidants 2020, 9, 272. [CrossRef] [PubMed]

10. Bulgari, R.; Baldi, A.; Ferrante, A.; Lenzi, A. Yield and quality of basil, Swiss chard, and rocket microgreens grown in a hydroponic system, New Zealand. J. Crop. Hortic. Sci. 2017, 45, 119-129. [CrossRef]

11. Murphy, C.J.; Llort, K.F.; Pill, W.G. Factors affecting the growth of microgreen table beet. Int. J. Veg. Sci. 2010, 16, 253-266. [CrossRef]

12. Kou, L.P.; Yang, T.B.; Luo, Y.G.; Liu, X.J.; Huang, L.H.; Codling, E. Pre-harvest calcium application increases biomass and delays senescence of broccoli microgreens. Postharvest Biol. Technol. 2014, 87, 70-78. [CrossRef]

13. Sun, J.; Kou, L.; Geng, P.; Huang, H.; Yang, T.; Luo, Y.; Chen, P. Metabolomic assessment reveals an elevated level of glucosinolate content in $\mathrm{CaCl} 2$ treated broccoli microgreens. J. Agric. Food Chem. 2015, 63, 1863-1868. [CrossRef]

14. Murphy, C.J.; Pill, W.G. Cultural practices to speed the growth of microgreen arugula (roquette; Eruca vesicaria subsp. sativa). J. Hortic. Sci. Biotechnol. 2010, 85, 171-176. [CrossRef]

15. Biró-Janka, B. Studies Regarding the Biology and Cultivation Technology of Basil (Ocimum basilicum L.) in the Eastern Part of the Transylvanian Plain. Ph.D. Thesis, USAMV Cluj-Napoca, Cluj-Napoca, Romania, 2020.

16. Al Murad, M.; Razi, K.; Jeong, B.R.; Samy, P.M.A.; Muneer, S. Light emitting diodes (LEDs) as agricultural lighting: Impact and its potential on improving physiology, flowering, and secondary metabolites of crops. Sustainability 2021, 13, 1985. [CrossRef]

17. El-Tantawy, W.H.; Temraz, A. Natural products for controlling hyperlipidemia: Review. Arch. Physiol. Biochem. 2018, 125, 128-135. [CrossRef] [PubMed]

18. Khan, I.A.; Abourashed, E.A. Leung's Encyclopedia of Common Natural Ingredients: Used in Food, Drugs, and Cosmetics, 3rd ed.; John Wiley \& Sons, Inc.: Hoboken, NJ, USA, 2010; pp. 74-75.

19. Grayer, R.J.; Kite, G.C.; Goldstone, F.J.; Bryan, S.E.; Paton, A.; Putievsky, E. Infraspecific taxonomy and essential oil chemotypes in sweet basil, Ocimum basilicum. Phytochemistry 1996, 43, 1033-1039. [CrossRef]

20. Carović-Stanko, K.; Orlić, S.; Politeo, O.; Strikić, F.; Kolak, I.; Milos, M.; Satovic, Z. Composition and antibacterial activities of essential oils of seven Ocimum taxa. Food Chem. 2010, 119, 196-201. [CrossRef]

21. Taie, H.A.A.; Abd-El, Z.; Salama, R.; Radwan, S. Potenial activity of basyl plants as a source of antioxidants and anticancer agents as affected by organic and bio-organic fertilization. Not. Bot. Horti Agrobot. Cluj-Napoca 2010, 38, 119-127. [CrossRef]

22. Oxenham, S.K.; Svoboda, K.P.; Walters, D.R. Antifungal activity of the essential oil of basil (Ocimum basilicum). J. Phytopathol. 2005, 153, 174-180. [CrossRef]

23. Lee, S.J.; Umano, K.; Shibamoto, T.; Lee, K.G. Identification of volatile components in basil (Ocimum basilicum L.) and thyme leaves (Thymus vulgaris L.) and their antioxidant properties. Food Chem. 2005, 91, 131-137. [CrossRef]

24. Politeo, O.; Jukic, M.; Milos, M. Chemical composition and antioxidant capacity of free volatile aglycones from basil (Ocimum basilicum L.) compared with its essential oil. Food Chem. 2007, 101, 379-385. [CrossRef]

25. Erler, F.; Ulug, I.; Yalcinkaya, B. Repellent activity of five essential oils against culex pipiens. Fitoterapia 2006, 77, 491-494. [CrossRef]

26. Chiriac, I.P.; Ulea, E. Study Regarding effectiveness of some plant extracts and different pesticides against an Erwinia amylovora (Burrill.) Winslow et al. strain isolated from quince. Cercet. Agron. Mold. 2012, 45, 69-74. [CrossRef]

27. Gonceariuc, M. Plante Medicinale și Aromatice Cultivate, 1st ed.; Academia de Științe a Moldovei: Chișinău, Moldova, 2008; pp. $18-25$.

28. Zhang, J.W.; Li, S.K.; Wu, W.J. The main chemical composition and in vitro antifungal activity of the essential oils of Ocimum basilicum Linn. var. Pilosum (Willd.) Benth. Molecules 2009, 14, 273-278. [CrossRef] [PubMed]

29. Chang, C.L.; Cho, I.K.; Li, Q.X. Insecticidal activity of basil oil, trans-anethole, estragole, and linalool to adult fruit flies Ceratitis capitata, Bactrocera dorsalis, and Bactrocera cucurbitae. J. Econ. Entomol. 2009, 102, 203-209. [CrossRef]

30. Ciocan, V. Plante Etnobotanice din România: Între Adevăr şi Pericol; Editura Ceres: Bucureşti, Romania, 2011; pp. 129-134.

31. Oshaghi, E.; Tavilani, H.; Khodadadi, I.; Goodarzi, M. Dill tablet: A potential anti-oxidant and anti-diabetic medicine. Asian Pac. J. Trop. Biomed. 2015, 5, 720-727. [CrossRef]

32. Zahra, A.A.; Al Fadhil, A.O. Antibacterial activity of Ocimum basilicum (Rehan) leaf extract against bacterial pathogens in Sudan. Am. J. Res. Commun. 2015, 3, 94-99.

33. Milică, C.I.; Roman, C.N.; Troia, D. Flora Medicinală a României; Editura Doxologia: Iaşi, Romania, $2012 ;$ p. 57.

34. Muntean, L.S.; Tămaş, M.; Muntean, S. Tratat de Plante Medicinale Cultivate şi Spontane, 2nd ed.; Edit. Risoprint: Cluj-Napoca, Romania, 2016; pp. 485-495. 
35. Araújo, S.V.; Sousa, J.P.D.; Pessôa, H.D.L.F.; Freitas, A.F.R.D.; Coutinho, H.D.M.; Alves, L.B.N.; Lima, E.O. Ocimum basilicum: Antibacterial activity and association study with antibiotics against bacteria of clinical importance. Pharm. Biol. 2016, 54, 863-867. [CrossRef] [PubMed]

36. Takwa, S.; Caleja, C.; Barreira, J.C.M.; Soković, M.; Achour, L.; Barros, L.; Ferreira, I.C.F.R. Arbutus unedo L. and Ocimum basilicum L. as sources of natural preservatives for food industry: A case study using loaf bread. LWT 2018, 88, 47-55. [CrossRef]

37. Amor, G.; Sabbah, M.; Caputo, L.; Idbella, M.; De Feo, V.; Porta, R.; Fechtali, T.; Mauriello, G. Basil essential oil: Composition, antimicrobial properties, and microencapsulation to produce active chitosan films for food packaging. Foods 2021, 10, 121. [CrossRef]

38. Tacchini, M.; Guevara, M.P.E.; Grandini, A.; Maresca, I.; Radice, M.; Angiolella, L.; Guerrini, A. Ocimum campechianum Mill. from Amazonian Ecuador: Chemical composition and biological activities of extracts and their main constituents (eugenol and rosmarinic acid). Molecules 2021, 26, 84. [CrossRef]

39. Bernáth, J.; Székely, J. Gyógy—És Aromanövények; Editura Mezőgazda: Budapesta, Hungary, 2006; pp. 367-370.

40. Purkayastha, J.; Nath, S.C. Composition of the camphor-rich essential oil of Ocimum basilicum L. native to Northeast India. J. Essent. Oil Res. 2006, 18, 332-334. [CrossRef]

41. Kutta, G. A Lamiaceae Családra Jellemző Illó És Nem Illó Terpén, Illetve Fenolos Komponensek Kivonása Szuperkritikus Fluid Extrakcióval; Universitatea Corvinus din Budapesta: Budapesta, Hungary, 2010; pp. 17-19.

42. Lawrence, B.M. A further examination of the variation of Ocimum basilicum L. Dev. Food Sci. 1988, 18, 161-170.

43. Koutsos, T.V.; Chatzopoulou, P.S.; Katsiotis, S.T. Effects of individual selection on agronomical and morphological traits and essential oil of a "Greek Basil" population. Euphytica 2009, 170, 365-370. [CrossRef]

44. Sestili, P.; Ismail, T.; Calcabrini, C.; Guescini, M.; Catanzaro, E.; Turrini, E.; Layla, A.; Akhtar, S.; Fimognari, C. The potential effects of Ocimum basilicum on health: A review of pharmacological and toxicological studies. Expert Opin. Drug Metab. Toxicol. 2018, 14, 679-692. [CrossRef]

45. Tungmunnithum, D.; Thongboonyou, A.; Pholboon, A.; Yangsabai, A. Flavonoids and other phenolic compounds from medicinal plants for pharmaceutical and medical aspects: An overview. Medicines 2018, 5, 93. [CrossRef] [PubMed]

46. Kumar, N.; Goel, N. Phenolic acids: Natural versatile molecules with promising therapeutic applications. Biotechnol. Rep. 2019, 24, e00370. [CrossRef]

47. Lee, J.; Scagel, C.F. Chicoric acid found in basil (Ocimum basilicum L.) Leaves. Food Chem. 2009, 115, 650-656. [CrossRef]

48. Surveswaran, S.; Cai, Y.; Corke, H.; Sun, M. Systematic evaluation of natural phenolic antioxidants from 133 indian medicinal plants. Food Chem. 2007, 102, 938-953. [CrossRef]

49. Kwee, E.M.; Niemeyer, E.D. Variations in phenolic composition and antioxidant properties among 15 basil (Ocimum basilicum L.) cultivars. Food Chem. 2011, 128, 1044-1050. [CrossRef]

50. Asghari, G.; Gholamali, H.; Mahmoudi, Z.; Asghari, M. Diurnal variation of essential oil components of Pycnocycla spinosa Decne. ex Boiss. Junidishapur J. Nat. Pharm. Maceutical Prod. 2014, 9, 35-38. [CrossRef]

51. Dzida, K. Nutrients contents in sweet basil (Ocimum basilicum L.) Herb depending on calcium carbonate dose and cultivar. Acta scientiarum Polonorum. Hortorum Cultus 2010, 9, 143-151.

52. Snežana, F. Basil (Ocimum basilicum L.) a source of valuable phytonutrients. Int. J. Clin. Nutr. Diet. 2017, 3, 118. [CrossRef]

53. Bîlteanu, G. Fitotehnie, 2nd ed.; Editura Ceres: Bucuresti, Romania, 2001; p. 544.

54. Fallahi, H.R.; Mohammadi, M.; Aghhavani-Shajari, M.; Ranjbar, F. Determination of germination cardinal temperatures in two basil (Ocimum basilicum L.) cultivars using non-linear regression models. J. Appl. Res. Med. Aromat. Plants 2015, 2, 140-145. [CrossRef]

55. Nadjafi, E.; Tabrizi, L.; Shabahang, J.; Mahdavi-Damghani, A.M. Cardinal germination temperatures of some medicinal plant species. Seed Technol. 2009, 31, 156-163.

56. Kumar, B. Prediction of germination potential in seeds of Indian basil (Ocimum basilicum L.). J. Crop. Improv. 2012, 26, 532-539. [CrossRef]

57. Zhou, D.; Jacob, B.; Ponder, M.A.; Welbaum, G.E. Germination response of six sweet basil (Ocimum basilicum) cultivars to temperature. Seed Technol. J. 2016, 37, 43-51.

58. Lariguet, P.; Ranocha, P.; De Meyer, M.; Barbier, O.; Penel, C.; Dunand, C. Identification of a hydrogen peroxide signaling pathway in the control of light-dependent germination in Arabidopsis. Planta 2013, 238, 381-395. [CrossRef]

59. Rakshit, A.; Singh, H.B. Advances in Seed Priming; Springer: Singapore, 2018; pp. 147-183. [CrossRef]

60. Noorhosseini, S.A.; Jokar, N.K.; Damalas, C.A. Improving seed germination and early growth of garden cress (Lepidium sativum) and basil (Ocimum basilicum) with hydro-priming. J. Plant Growth Regul. 2018, 37, 323-334. [CrossRef]

61. Delavari, P.; Baghizadeh, A.; Enteshari, S.; Kalantari, K.; Yazdanpanah, A.; Mousavi, E.A. The effects of salicylic acid on some of biochemical and morphological characteristic of Ocimum basilicucm under salinity stress. Aust. J. Basic Appl. Sci. 2010, 4, 4832-4845.

62. Elhindi, K.M.; Dewir, Y.H.; Asrar, A.W.; Abdel-Salam, E.; Sharaf El-Din, A.; Ali, M. Improvement of seed germination in three medicinal plant species by plant growth regulators. HortScience 2016, 51, 887-891. [CrossRef]

63. Rusu, T. Agrotehnica, 1st ed.; Editura Risoprint: Cluj-Napoca, Romania, 2005; p. 68. 
64. Sabzalian, M.R.; Heydarizadeh, P.; Zahedi, M.; Boroomand, A.; Agharockh, M.; Sahba, M.R.; Schoefs, B. High performance of vegetables, flowers, and medicinal plants in a red-blue LED incubator for indoor plant production. Agron. Sustain. Dev. 2014, 34, 879-886. [CrossRef]

65. Kopsell, D.A.; Morrow, R.C.; Sams, C.R. Blue wavelengths from LED lighting increase nutritionally important metabolites in specialty crops. HortScience 2015, 50, 1285-1288. [CrossRef]

66. Ouzounis, T.; Heuvelink, E.; Ji, Y.; Schouten, H.J.; Visser, R.G.F.; Marcelis, L.F.M. Blue and red LED lighting effects on plant biomass, stomatal conductance, and metabolite content in nine tomato genotypes. Acta Hortic. 2016, 1134, 251-258. [CrossRef]

67. Lobiuc, A.; Vasilache, V.; Oroian, M.; Stoleru, T.; Burducea, M.; Pintilie, O.; Zamfirache, M.M. Blue and red LED illumination improves growth and bioactive compounds contents in acyanic and cyanic Ocimum basilicum L. microgreens. Molecules 2017, 22, 2111. [CrossRef] [PubMed]

68. Ying, Q.L.; Kong, Y.; Zheng, Y.B. Growth and appearance quality of four microgreen species under light-emitting diode lights with different spectral combinations. Hortscience 2020, 55, 1399-1405. [CrossRef]

69. Singh, D.; Basu, C.; Meinhardt-Wollweber, M.; Roth, B. LEDs for energy efficient greenhouse lighting. Renew. Sustain. Energy Rev. 2015, 49, 139-147. [CrossRef]

70. Samuolienè, G.; Brazaitytè, A.; Sirtautas, R.; Sakalauskienè, S.; Jankauskiene, J.; Duchovskis, P.; Novickovas, A. The impact of supplementary short-term red LED lighting on the antioxidant properties of microgreens. Acta Hortic. 2012, 956, 649-655. [CrossRef]

71. Leroy, C.; Petitclerc, F.; Orivel, J.; Corbara, B.; Carrias, J.F.; Dejean, A.; Céréghino, R. The influence of light, substrate and seed origin on the germination and establishment of ant-garden bromeliad. Plant Biol. 2017, 19, 70-78. [CrossRef]

72. Jacobsen, J.V.; Barrero, J.M.; Hughes, T.; Julkowska, M.; Taylor, J.M.; Xu, Q.; Gubler, F. Roles for blue light, jasmonate and nitric oxide in the regulation of dormancy and germination in wheat grain (Triticum aestivum L.). Planta 2013, 238, 121-138. [CrossRef]

73. Wang, Y.; Folta, K.M. Contributions of green light to the plant growth and development. Am. J. Bot. 2013, 100, 70-78. [CrossRef]

74. Flores, A.M.; Schutte, B.J.; Shukla, M.K.; Picchioni, G.A.; Ulery, A.L. Time-integrated measurements of seeds germination for salt tolerant plant species. Seed Sci. Technol. 2015, 43, 541-547. [CrossRef]

75. Footitt, S.; Huang, Z.; Clay, H.A.; Mead, A.; Finch-Savage, W.E. Temperature, light and nitrate sensing coordinate Arabidopsis seed dormancy cycling, resulting in winter and summer annual phenotypes. Plant. J. 2013, 74, 1003-1015. [CrossRef]

76. Renade, S.S.; Gil, M.R.G. Application of monochromatic blue light during germination and hypocotyl development improves outplanted Scot spine (Pinus sylvestris L.) trees performance. For. Ecol. Manag. 2016, 361, 368-374. [CrossRef]

77. Rahman, M.M.; Vasiliev, M.; Alameh, K. LED illumination spectrum manipulation for increasing the yield of sweet basil (Ocimum basilicum L.). Plants 2021, 10, 344. [CrossRef] [PubMed]

78. Samuolienè, G.; Brazaitytè, A.; Viršilè, A.; Jankauskienè, J.; Sakalauskienè, S.; Duchovskis, P. Red light-dose or wavelengthdependent photoresponse of antioxidants in herb microgreens. PLoS ONE 2016, 11, e0163405. [CrossRef] [PubMed]

79. Brazaitytë, A.; Virsilë, A.; Samuolienë, G.; Jankauskienë, J.; Sakalauskienë, S.; Sirtautas, R.; Novièkovas, A.; Dabašinskas, L.; Vaštakaitë, V.; Miliauskienë, J.; et al. Light quality: Growth and nutritional value of microgreens under indoor and greenhouse conditions. Acta Hortic. 2016, 1134, 277-284. [CrossRef]

80. Vaštakaitè, V.; Viršilè, A.; Brazaitytè, A.; Samuolienè, G.; Jankauskienè, J.; Sirtautas, R.; Duchovskis, P. The effect of UV-a supplemental lighting on antioxidant properties of Ocimum basilicum L. microgreens in greenhouse. In Proceedings of the 7th International Scientific Conference Rural Development, Lithuania, 19-20 November 2015. [CrossRef]

81. Sakamoto, M.; Uenishi, M.; Miyamoto, K.; Suzuki, T. Effect of root-zone temperature of the growth and fruit quality of hydroponically grown strawberry plants. J. Agric. Sci. 2016, 8, 122-131. [CrossRef]

82. Waller, P.; Yitayew, M. Hydroponic irrigation systems. Environ. Sci. 2016, 369-386. [CrossRef]

83. Bita, C.E.; Gerats, T. Plant tolerance to high temperature in a changing environment: Scientific fundamentals and production of heat stress-tolerant crops. Front. Plant. Sci. 2013, 4, 273. [CrossRef]

84. Chun, C.; Takakura, T. Rate of root respiration of lettuce under various dissolved oxygen concentrations in hydroponics. Environ. Control. Biol. 1993, 32, 125-135. [CrossRef]

85. Cornejo, H.A.C.; Rodriguez, L.M.; Vergara, A.G.; Bucio, J.L. Trichoderma modulates stomatal aperture and leaf transpiration through an abscisic acid-dependent mechanism in arabidopsis. J. Plant. Growth Regul. 2015, 34, 425-434. [CrossRef]

86. Roosta, H.R.; Bagheri, M.H.; Hamidpour, M.; Roozban, M.R. Interactive effects of nitrogen form and oxygen concentration on growth and nutritional status of eggplant in hydroponics. J. Agric. Sci. Technol. 2016, 18, 731-739.

87. Sakamoto, M.; Suzuki, T. Elevated root-zone temperature modulates growth and quality of hydroponically grown carrots. Agric. Sci. 2015, 6, 749-757. [CrossRef]

88. Msayleb, N. Soil Ozonation as a Sustainable Alternative to Methyl Bromide Fumigation and Synthetic Pesticides. Ph.D. Thesis, Iowa State University, Ames, IA, USA, 2014. [CrossRef]

89. Oliveira, L.L.; Macedo, A.F. The effect of light quality, temperature and substrate on seed germination and epicotyl development of Carapa guianensis, a multi-use neotropical tree. J. Med. Plants Res. 2015, 9, 582-593. [CrossRef]

90. Baenas, N.; Garcia-Viguera, C.; Moreno, D.A. Elicitation: A tool for enriching the bioactive composition of foods. Molecules 2014, 19, 13541-13563. [CrossRef] [PubMed]

91. Wang, L.C.; Xue, X.Z.; Li, Y.K.; Li, F.; Zhang, F.; Guo, W.Z. Effect of pH upper control limit on nutrient solution component and water spinach growth under hydroponics. Adv. J. Food Sci. Technol. 2015, 9, 717-721. [CrossRef] 
92. Chitarra, W.; Pugliese, M.; Gilardi, G.; Gullino, M.L.; Garibaldi, A. Effect of silicates and electrical conductivity on Fusarium wilt of hydroponically grown lettuce. Commun. Agric. Appl. Biol. Sci. 2013, 78, 555-557. [PubMed]

93. Bulgari, R.; Negri, M.; Santoro, P.; Ferrante, A. Quality evaluation of indoor-grown microgreens cultivated on three different substrates. Horticulturae 2021, 7, 96. [CrossRef]

94. Manawasinghe, N.K.G.K.R.; Weerasekara, S.H.; Karunaratne, C.S.L.M.; Weerakkody, W.A.P.; Kulapala, B. Influence of substrate and supplementary LED lighting on vertical farming of basil (Ocimum basilicum L.) and pak choi (Brassica rapa var. chinensis). Asian J. Agric. Hortic. Res. 2021, 7, 42-52. [CrossRef]

95. Puccinelli, M.; Malorgio, F.; Rosellini, I.; Pezzarossa, B. Production of selenium-biofortified microgreens from selenium-enriched seeds of basil. J. Sci. Food Agric. 2019, 99, 5601-5605. [CrossRef]

96. Scagel, F.C.; Lee, J.; Mitchell, J.N. Salinity from $\mathrm{NaCl}$ changes the nutrient and polyphenolic composition of basil leaves. Ind. Crop. Prod. 2019, 127, 119-128. [CrossRef]

97. Saha, S.; Monroe, A.; Day, M.R. Growth, yield, plant quality and nutrition of basil (Ocimum basilicum L.) under soilless agricultural systems. Ann. Agric. Sci. 2016, 61, 181-186. [CrossRef]

98. Walters, K.J.; Currey, C.J. Hydroponic greenhouse basil production: Comparing systems and cultivars. HortTechnology 2015, 25, 645-650. [CrossRef]

99. Kiferle, C.; Maggini, R.; Pardossi, A. Influence of nitrogen nutrition on growth and accumulation of rosmarinic acid in sweet basil (Ocimum basilicum L.) grown in hydroponic culture. Aust. J. Crop. Sci. 2013, 7, 321-327. 